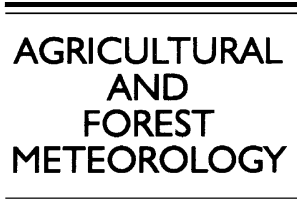

\title{
Foliar morphology and canopy nitrogen as predictors of light-use efficiency in terrestrial vegetation
}

\author{
D. Scott Green ${ }^{\mathrm{a}, *}$, John E. Erickson ${ }^{\mathrm{b}}$, Eric L. Kruger ${ }^{\mathrm{b}}$ \\ ${ }^{a}$ Ecosystem Science and Management, University of Northern British Columbia, Prince George, BC, Canada V2N $4 Z 9$ \\ ${ }^{\mathrm{b}}$ Department of Forest Ecology and Management, University of Wisconsin, Madison, WI 53706, USA
}

Received 22 April 2002; received in revised form 10 October 2002; accepted 17 October 2002

\begin{abstract}
The net primary productivity (NPP) of a plant community is often positively and linearly related to the amount of photosynthetically active radiation absorbed by its canopy (APAR). The slope of this relationship is governed by the efficiency ( $\varepsilon$ ) of APAR use in biomass production (NPP $=$ APAR $\times \varepsilon$ ). This intuitive model offers a promising means of generating large-scale NPP estimates, but its utility is compromised by our inability to explain considerable differences in $\varepsilon$ across species, functional groups, and environments. Using data from the literature, we examined the possibility that variation in $\varepsilon$ was governed largely by two chemical and morphological characteristics of the vegetation, canopy nitrogen content $\left(N_{\text {canopy }}\right)$ and the canopy average for leaf mass per unit area $\left(M_{\text {area }}\right)$. Specifically, we hypothesized that $\varepsilon$ was positively related to the quotient of $N_{\text {canopy }}$ (adjusted for the fraction of incident PAR absorbed by the canopy, $f_{\mathrm{PAR}}$ ) and $M_{\text {area }}$. This $\varepsilon$ index accounts for the dependence of light utilization on the quantity of photosynthetic "machinery" $\left(N_{\text {canopy }}\right)$ and its inherent efficiency, which is inversely related to $M_{\text {area }}$. Across a wide array of $C_{3}$ species, functional groups and environments, $\varepsilon$ (based on aboveground NPP) was strongly and positively related to $\left[N_{\text {canopy }} / f_{\mathrm{PAR}}\right] / M_{\text {area }}\left(r^{2}=0.85, P<0.0001\right)$. Adoption of the index as a basis for estimating $\varepsilon$ could improve APAR-based predictions of terrestrial NPP, agricultural crop yield and vegetation responses to global change.
\end{abstract}

(C) 2002 Elsevier Science B.V. All rights reserved.

Keywords: Light-use efficiency; Leaf nitrogen content; Leaf mass per area; Leaf area index; Net primary productivity

\section{Introduction}

Vegetation requires light energy to convert atmospheric $\mathrm{CO}_{2}$ into essential organic compounds required for plant growth and maintenance. Accordingly, plant biomass production by terrestrial vegetation has been observed to be strongly and positively related to the canopy absorption of photosynthetically active radiation (APAR; Monteith, 1972). The proportional relationship between net primary productivity (NPP)

\footnotetext{
* Corresponding author. Tel.: +1-250-960-5817; fax: +1-250-960-5539.

E-mail address: greens@unbc.ca (D. Scott Green).
}

and APAR, known as the light-use efficiency (LUE) or epsilon $(\varepsilon)$ model, is commonly used to explain and/or predict NPP variation in agricultural and forest ecosystems (Monteith, 1977; Jarvis and Leverenz, 1983; Ruimy et al., 1994; Runyon et al., 1994; Field et al., 1995; Gower et al., 1999; Sinclair and Muchow, 1999). It is also viewed as a potentially effective approach for modeling the responses of NPP to global change (Field et al., 1995; Haxeltine and Prentice, 1996; Hui et al., 2001).

The relationship between plant productivity and APAR is governed by $\varepsilon$ (defined either as NPP/APAR or the slope of NPP vs. APAR), which integrates all photosynthetic and respiratory processes. The $\varepsilon$ 
model offers several unique advantages in that it is uncomplicated, soundly based physiologically (Jarvis and Leverenz, 1983; Medlyn, 1998), and applicable to remote sensing (Landsberg et al., 1997). However, the operational potential of the $\varepsilon$ model suffers from some critical shortcomings. First, accurate estimates of $\varepsilon$ are difficult and expensive to acquire. And, contrary to the results of initial studies with crop species (Monteith, 1977), $\varepsilon$ has been found to vary considerably across a broader array of species, functional groups, and ecosystems (Ruimy et al., 1994; Gower et al., 1999; Sinclair and Muchow, 1999; Campbell et al., 2001; Green et al., 2001).

Differences in $\varepsilon$ have been related to numerous intrinsic and extrinsic factors, including species, photosynthetic pathway, leaf gas exchange and nutrient content, soil resource availability, atmospheric vapor pressure deficit, temperature and radiation environment (Sinclair and Muchow, 1999). Some studies have attempted to resolve variation in $\varepsilon$ by exploring these and other potential determinants (Runyon et al., 1994; McMurtrie et al., 1994; Dewar, 1996). For example, McMurtrie et al. (1994) used a physiological process model to predict the responses of $\varepsilon$ to environmental variation. While such efforts provide valuable information, their requirement for extensive plant ecophysiological input make them somewhat unwieldy and expensive to implement. Alternatively, Field et al. (1995) suggested that a more accessible $\varepsilon$ model might be created by exploiting the propensity of plants to integrate the influences of environmental conditions through adaptation and acclimation, such as changes in morphology and resource allocation, to accommodate ephemeral as well as chronic environmental constraints. In this vein, we hypothesize that $\varepsilon$ is governed largely by two properties of the canopy, its total $\mathrm{N}$ content $\left(N_{\text {canopy }}, \mathrm{kg} \mathrm{N} \mathrm{ha}^{-1}\right)$ and its average leaf mass per unit area $\left(M_{\text {area }}, \mathrm{g} \mathrm{m}^{-2}\right)$, which together capture much of the genetic and environmentally mediated variation in canopy photosynthetic potential.

Specifically, we hypothesize that there is a straightforward theoretical link between $\varepsilon$ and an index that combines $N_{\text {canopy }}$ and $M_{\text {area }}$. The $\mathrm{N}$ capital in a canopy is generally proportional to the amount of photosynthetic enzymes, pigments and electron-transport compounds available to utilize APAR (Field and Mooney, 1986; Evans, 1989). Based on the assumption that efficiency of light use at any particular moment is a function of the relative amount of photosynthetic machinery per unit of light absorbed, $N_{\text {canopy }}$ is divided by the fraction of incident PAR absorbed in the canopy $\left(f_{\text {PAR }}\right)$. This modification of $N_{\text {canopy }}$ helps to clarify its direct influence on $\varepsilon$ as opposed to its role in canopy PAR absorption (Dewar, 1996; Haxeltine and Prentice, 1996). Studies (e.g., Reich et al., 1997; Poorter and Evans, 1998; Green and Kruger, 2001) have shown that photosynthetic N-use efficiency is inversely related to $M_{\text {area }}$ across a wide spectrum of species and functional groups, and thus $M_{\text {area }}$ is assigned a similar role as the denominator in our $\varepsilon$ index. Thus, the index becomes $\left[N_{\text {canopy }} / f_{\text {PAR }}\right] / M_{\text {area }}$. Our primary objective in the present study is to assess, through analysis of published data, the degree to which variation in $\varepsilon$ within and across functional groups and environments is explained by the index in comparison with models containing its component variables alone or related attributes (e.g., leaf $\mathrm{N}$ content) that are regarded as potentially important determinants (Sinclair and Muchow, 1999).

\section{Materials and methods}

Most data on $\varepsilon$ and related canopy attributes were obtained from published studies ${ }^{1}$ (Table 1 ) involving numerous $\mathrm{C}_{3}$ species from several functional groups, including evergreen woody species, deciduous woody species and herbaceous species (e.g., annual and perennial forbs, grasses and legumes). As few of these studies measured total NPP, calculations of $\varepsilon$ for this analysis were based on aboveground NPP. All data were standardized and converted to the same units to avoid inconsistencies often associated with $\varepsilon$ modeling (Gower et al., 1999; Sinclair and Muchow, 1999). For example, $\varepsilon$ was taken to be the quotient of aboveground biomass increment $\left(\mathrm{g} \mathrm{m}^{-2}\right)$ and the amount of photosynthetically active radiation intercepted by the canopy (IPAR, $\mathrm{MJ} \mathrm{m}^{-2}$ ) during a given time interval. As APAR is rarely measured (because of the difficulty of obtaining canopy reflectance), and IPAR was used as a necessary surrogate. This approach is regarded as a reasonable alternative given that APAR and IPAR

\footnotetext{
${ }^{1}$ Of the 105 data used in this analysis, 12 were taken from the dissertation of Green (1998). The methodology used to acquire these data paralleled that described in Green et al. (2001).
} 
Table 1

Data on LUE $(\varepsilon)$ and associated canopy attributes, including canopy $\mathrm{N}$ content $\left(N_{\text {canopy }}\right)$, the canopy average for leaf mass per unit area $\left(M_{\text {area }}\right)$, leaf area index $(L)$, and the canopy average for leaf $\mathrm{N}$ concentration $\left(N_{\text {mass }}\right)$, used in the present analysis ${ }^{\mathrm{a}}$

\begin{tabular}{|c|c|c|c|c|c|c|c|}
\hline Species & $n$ & $\begin{array}{l}N_{\text {canopy }} \\
\left(\mathrm{kg} \mathrm{Nha}^{-1}\right)\end{array}$ & $\begin{array}{l}M_{\text {area }} \\
\left(\mathrm{g} \mathrm{m}^{-2}\right)\end{array}$ & $\begin{array}{l}L \\
\left(\mathrm{~m}^{2} \mathrm{~m}^{-2}\right)\end{array}$ & $\begin{array}{l}N_{\text {mass }} \\
\left(\mathrm{mgg}^{-1}\right)\end{array}$ & $\varepsilon\left(\mathrm{g} \mathrm{MJ}^{-1}\right)$ & Reference \\
\hline Acer saccharum Marsh. & 1 & 47 & 46 & 6.2 & 16.2 & 1.18 & Green (1998) \\
\hline Alnus rubra Bong. & 1 & 112 & 92 & 3.9 & 25.0 & 0.89 & Runyon et al. (1994), Pierce et al. (1994) \\
\hline Arachis hypogaea $\mathrm{L}$. & 2 & $74-91$ & $48-65$ & $3.9-4.8$ & $29.2-39.6$ & $1.83-2.44$ & Wright and Hammer (1994) \\
\hline Dactylis glomerata $\mathrm{L}$. & 6 & $12-39$ & $31-42$ & $1.0-4.2$ & $21.3-38.0$ & $0.71-1.78$ & Duru et al. (1995) \\
\hline Festuca arundinacea Schreb. & 6 & $13-51$ & $44-66$ & $1.0-3.9$ & $20.0-32.3$ & $0.87-2.09$ & Duru et al. (1995) \\
\hline Fraxinus pennsylvanica Marsh. & 2 & $30-59$ & $68-78$ & $2.8-3.6$ & $15.5-21.2$ & $0.66-0.77$ & Green (1998) \\
\hline F. uhdei (Wenzig) Lingelsh & 8 & $5-69$ & $67-190$ & $0.3-4.2$ & $10.8-21.7$ & $0.09-1.31$ & Ares and Fownes (2001) \\
\hline Gossypium hirsutum L. & 12 & $\mathrm{NA}^{\mathrm{b}}$ & NA & $2.1-3.1$ & $33.8-47.6$ & $1.18-2.30$ & Sadras and Wilson (1997) \\
\hline Helianthus annuus $\mathrm{L}$. & 4 & $9-41$ & $62-77$ & $0.4-2.1$ & $22.6-31.0$ & $0.40-1.70$ & Geeske et al. (1997) \\
\hline H. cannabinus $\mathrm{L}$. & 4 & $27-86$ & $43-51$ & $2.2-5.4$ & $23.0-37.7$ & $1.63-2.89$ & Muchow (1990) \\
\hline Juglans nigra $\mathrm{L}$. & 1 & 57 & 59 & 4.1 & 23.4 & 1.31 & Green (1998) \\
\hline Juniperus occidentalis Hook. & 1 & 24 & 588 & 0.4 & 11 & 0.29 & Runyon et al. (1994), Pierce et al. (1994) \\
\hline Mixed deciduous hardwood stands & 6 & $39-48$ & $68-102$ & $2.6-4.5$ & $15.0-18.3$ & $0.39-0.47$ & Jose and Gillespie (1996) \\
\hline Oryza sativa $\mathrm{L}$. & 8 & NA & NA & $6.1-7.6$ & $27.5-32.6$ & $2.09-2.77$ & Kiniry et al. (2001) \\
\hline Phleum pratense $\mathrm{L}$. & 4 & NA & NA & $1.4-5.8$ & $18.7-42.0$ & $1.16-2.55$ & Belanger and Richards (1997) \\
\hline Pinus banksiana Lamb. & 1 & 105 & 228 & 2.8 & 16.4 & 0.71 & Green (1998) \\
\hline Pinus elliottii Engelm. & 7 & $14-83$ & $240-327$ & $0.7-3.0$ & $7.3-10.9$ & $0.11-0.50$ & $\begin{array}{l}\text { Gholz and Fisher (1982), Gholz et al. (1985), } \\
\text { Gholz et al. (1991), Teskey et al. (1994) }\end{array}$ \\
\hline Pinus ponderosa Laws. & 2 & $18-22$ & 285 & 1.1 & $9.6-12$ & $0.29-0.30$ & Runyon et al. (1994), Pierce et al. (1994) \\
\hline Pinus radiata $\mathrm{D}$. Don & 5 & $91-197$ & $258-294$ & $0.7-2.8$ & $7.7-14.5$ & $0.67-1.37$ & $\begin{array}{l}\text { Raison and Myers (1992), Raison et al. (1992), } \\
\text { Snowdon and Benson (1992) }\end{array}$ \\
\hline Pinus resinosa Ait. & 2 & $134-167$ & $233-248$ & $4.4-5.9$ & $12.2-12.3$ & $0.80-0.98$ & Green (1998) \\
\hline Pinus strobus $\mathrm{L}$. & 1 & 121 & 146 & 5.9 & 14.0 & 1.26 & Green (1998) \\
\hline Picea glauca (Moench) Voss & 2 & $164-199$ & $247-260$ & $4.0-7.1$ & $11.3-15.8$ & $0.83-0.95$ & Green (1998) \\
\hline $\begin{array}{l}\text { Picea Sitchensis (Bong.) Carr., Tsuga } \\
\text { heterophylla (Raf.) Sarg. }\end{array}$ & 1 & 100 & 127 & 5.3 & 11 & 0.57 & Runyon et al. (1994), Pierce et al. (1994) \\
\hline Populus spp. & 5 & $60-87$ & $62-79$ & $4.1-6.3$ & $22.0-31.7$ & $1.07-2.22$ & Green et al. (2001) \\
\hline Populus tremuloides Michx. & 2 & $56-59$ & $57-71$ & $3.6-4.0$ & $23.0-24.7$ & $1.05-1.25$ & Green (1998) \\
\hline Pseudotsuga menziesii (Mirb.) Franco. & 1 & 119 & 185 & 4.0 & 11.7 & 0.57 & Runyon et al. (1994), Pierce et al. (1994) \\
\hline $\begin{array}{l}\text { Tsuga heterophylla (Raf.) Sarg., } \\
\text { Pseudotsuga menziesii (Mirb.) Franco. }\end{array}$ & 2 & $197-211$ & $141-158$ & 8.7 & $12.9-13.8$ & $0.80-0.95$ & Runyon et al. (1994), Pierce et al. (1994) \\
\hline Triticum durum Desf. & 3 & NA & NA & $4.0-5.1$ & $45.4-46.3$ & $1.89-2.58$ & Giunta et al. (1995) \\
\hline Tsuga mertensiana (Bong.) Carr. & 1 & 62 & 333 & 2.8 & 9.9 & 0.52 & Runyon et al. (1994), Pierce et al. (1994) \\
\hline $\begin{array}{l}\text { Tussock, shrub, heath and wetland } \\
\text { sedge ecosystems }\end{array}$ & 4 & $6-32$ & $75-237$ & $0.2-1.4$ & $13.8-31.5$ & $0.38-0.81$ & Shaver and Chapin (1991) \\
\hline
\end{tabular}

${ }^{\text {a }}$ Where data on multiple treatments or replications were available, ranges for the values are provided

${ }^{\mathrm{b}} \mathrm{NA}$ indicates that data were not available for the target variable in the reference. 
generally agree within 4\% (Gower et al., 1999; Russell et al., 1989). When $\varepsilon$ had originally been calculated using total solar radiation, we divided $\varepsilon$ by 0.46 to convert to a PAR basis (Weiss and Norman, 1985). In studies where $\varepsilon$ was not reported (Gholz and Fisher, 1982; Shaver and Chapin, 1991; Jose and Gillespie, 1996) we calculated it based on ANPP and incident radiation data. In these instances we calculated IPAR based on a 30-year average (1961-1990) of total solar radiation measured during the growing season at a monitoring station near each study site (Renewable Resources Data Center, 2002). The period during which $\varepsilon$ was measured ranged from several weeks to one year among studies. For annual crop species, $\varepsilon$ was based on crop growth before anthesis. In the case of Runyon et al. (1994), $\varepsilon$ was readjusted to account only for losses in APAR owing to freezing temperatures.

It was frequently necessary to derive target variables from related data. In a number of cases the canopy average for leaf mass per unit area $\left(M_{\text {area }}\right.$, $\mathrm{g} \mathrm{m}^{-2}$ ) was calculated as the quotient of total foliar biomass $\left(\mathrm{g} \mathrm{m}^{-2}\right)$ and leaf area index $\left(L, \mathrm{~m}^{2} \mathrm{~m}^{-2}\right)$.

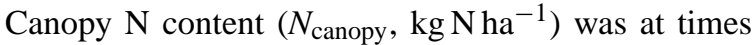
determined as the product of $L$ and leaf $\mathrm{N}$ content $\left(N_{\text {area }}, \mathrm{g} \mathrm{N} \mathrm{m}^{-2}\right)$ or total foliar biomass and leaf $\mathrm{N}$ concentration $\left(N_{\text {mass }}, \mathrm{mg} \mathrm{Ng}^{-1}\right)$. The proposed $\varepsilon$ index was calculated as $\left[N_{\text {canopy }} / f_{\mathrm{PAR}}\right] / M_{\text {area }}$ or its mathematical equivalent $\left[L N_{\text {mass }} / 100\right] / f_{\mathrm{PAR}}$ (when $M_{\text {area }}$ was not available). When target variables were measured more than once during a growth interval, we took the mean of those values. Similarly, when index components were simultaneously measured more than once, we used index values calculated on each occasion to generate a mean. For example, Kiniry et al. (2001) measured $L$ and $N_{\text {mass }}$ on five sampling dates for each of two years, from 13 May 1999 to 22 July 1999 and 16 May 2000 to 12 July 2000 . The index was determined at each sampling date and averaged across the five dates per year. Likewise, in the case of Belanger and Richards (1997) we calculated a mean for the index based on values from each of five sampling dates (from 10 May 1993 to 18 June 1993). We did not use the summer data from Belanger and Richards (1997) pertaining to crop growth after mowing. For Giunta et al. (1995), $\varepsilon$ was determined through the period from stem elongation until heading, and corresponding index values were averages of seven $L$ and $N_{\text {mass }}$ measurements made during the same time period. A similar strategy was used in the case of Sadras and Wilson (1997) between days 56-112 in the first experiment and days 60-130 in the second experiment. When $f_{\mathrm{PAR}}$ was not provided, it was calculated as $1-\mathrm{e}^{-k L}$ (Gower et al., 1999). The light extinction coefficient $(k)$ was frequently reported, but where it was missing we used published species-specific values or, for Shaver and Chapin (1991), a default value of 0.5 (Campbell and Norman, 1998).

Combining all data, relationships between $\varepsilon$ and its potential determinants, including the proposed $\varepsilon$ index, $N_{\text {mass }}, N_{\text {area }}, N_{\text {canopy }}, L$ and $M_{\text {area }}$, were analyzed by linear regression procedures in SAS (SAS, 2000). Relationships were examined both within and across functional groups.

\section{Results}

Data from a variety of species in different functional groups and environments provided considerable diversity in $\varepsilon$ (e.g., $0.09 \mathrm{~g} \mathrm{MJ}^{-1}$ in Fraxinus uhdei to $2.89 \mathrm{~g} \mathrm{MJ}^{-1}$ in Hibiscus cannabinus) and several of its potential determinants, including $M_{\text {area }}, N_{\text {mass }}, N_{\text {area }}$, $N_{\text {canopy }}$ and $L$ (Table 1, Figs. 1-3). Among canopy variables, the strongest predictor of $\varepsilon$ across all data was the index $\left[N_{\text {canopy }} / f_{\text {PAR }}\right] / M_{\text {area }}$, or its mathematical equivalent $\left(L N_{\text {mass }} / 100\right) / f_{\mathrm{PAR}}$ (Fig. 1). ${ }^{2}$ Notably, the slope of the relation between $\varepsilon$ and the index did not differ among functional groups $(P=0.79)$. But at a given index value, $\varepsilon$ was about $0.3 \mathrm{~g} \mathrm{MJ}^{-1}$ higher $(P<0.0001)$ for herbaceous species than for evergreen or deciduous woody plants.

While the index was more effective than any single canopy trait in explaining $\varepsilon$ variation across all data (Figs. 1-3), $\varepsilon$ was strongly and positively correlated

\footnotetext{
2 The potential for autocorrelation between $\varepsilon$ and the index exists because APAR is present in the denominator of both variables $\left(\varepsilon=\mathrm{NPP} / \mathrm{APAR} ;\right.$ index $=\left(N_{\text {canopy }} / M_{\text {area }}\right) /(\mathrm{APAR} / \mathrm{PAR})$, where $\mathrm{PAR}$ is incident PAR in $\mathrm{MJ} \mathrm{m}^{-2}$ ground area per year). Removal of APAR from both variables leaves NPP and PAR $\times N_{\text {canopy }} / M_{\text {area }}$. In the present analysis, the strength of the relation between ANPP and PAR $\times N_{\text {canopy }} / M_{\text {area }}\left(r^{2}=0.76, P<0.0001\right)$ was very similar to that between $\varepsilon$ and the index $\left(r^{2}=0.79, P<0.0001\right)$, based on the subset of data where PAR was available $(n=71)$. This result indicated that there was minimal autocorrelation between $\varepsilon$ and the index in our analysis.
} 


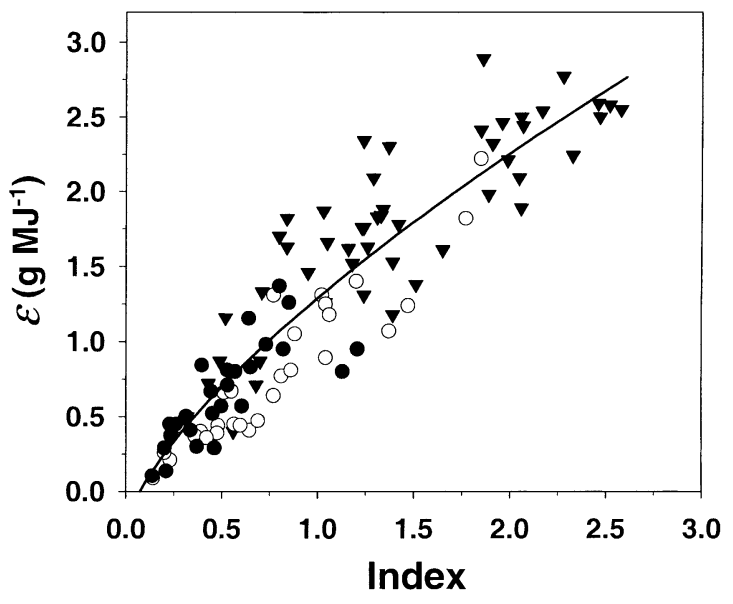

Fig. 1. Relationship between LUE $(\varepsilon)$ and the index, calculated either as (1) $\left[N_{\text {canopy }} / f_{\text {PAR }}\right] / M_{\text {area }}$, where $N_{\text {canopy }}$ is the canopy $\mathrm{N}$ content $\left(\mathrm{kg} \mathrm{Nha}^{-1}\right), f_{\mathrm{PAR}}$ the fraction of incident PAR intercepted by the canopy, and $M_{\text {area }}$ the canopy average for leaf mass per area $\left(\mathrm{g} \mathrm{m}^{-2}\right)$, or (2) $\left[L N_{\text {mass }} / 100\right] / f_{\mathrm{PAR}}$, where $L$ is the leaf area index $\left(\mathrm{m}^{2} \mathrm{~m}^{-2}\right)$ and $N_{\text {mass }}$ the canopy average for leaf $\mathrm{N}$ concentration $\left(\mathrm{mg} \mathrm{g}^{-1}\right)$. The regression across all data is $\varepsilon=1.54(\text { index })^{0.7}-0.25\left(r^{2}=0.85, P<0.0001, n=105\right)$. Functional group symbols: deciduous woody plants, open circles; evergreen woody plants, filled circles; herbaceous species, filled triangles. with $N_{\text {mass }}, N_{\text {canopy }}$ and/or $L$ in particular functional groups. A sizeable amount of $\varepsilon$ variation was explained by $N_{\text {mass }}$ within the deciduous woody group $\left(r^{2}=\right.$ $0.57, P<0.0001$, Fig. 2 A), by $N_{\text {canopy }}$ within each of the three groups $\left(r^{2}=0.63-0.81, P<0.0001\right.$, Fig. 2C), and by $L$ within the herbaceous and deciduous woody groups $\left(r^{2}=0.63-0.73, P<0.0001\right.$, Fig. 3A). Furthermore, a significant inverse relationship between $\varepsilon$ and $M_{\text {area }}$ was observed in the deciduous woody group $\left(r^{2}=0.39, P=0.0003\right.$, Fig. 3B). In each of these cases $\varepsilon$ was significantly related to a component of the index that varied much more than its counterpart. For instance, among herbaceous data the range in $N_{\text {canopy }}$ (significantly correlated with $\varepsilon$ ) was about 10 -fold, while the variation in $M_{\text {area }}$ (not significantly correlated with $\varepsilon$ ) was less than 5 -fold.

\section{Discussion}

\subsection{Mechanistic links between $\varepsilon$ and the index}

Numerous studies provide support for the widespread use of $\mathrm{N}$ content as an index of the amount of photosynthetic enzymes, pigments and electron-

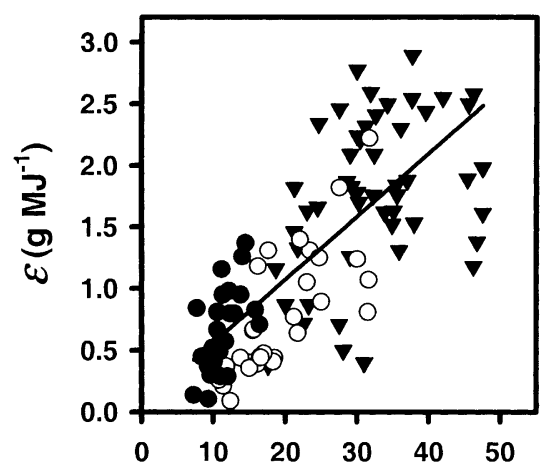

(A)

$$
N_{\text {mass }}\left(\mathrm{mg} \mathrm{N} \mathrm{g}^{-1}\right)
$$

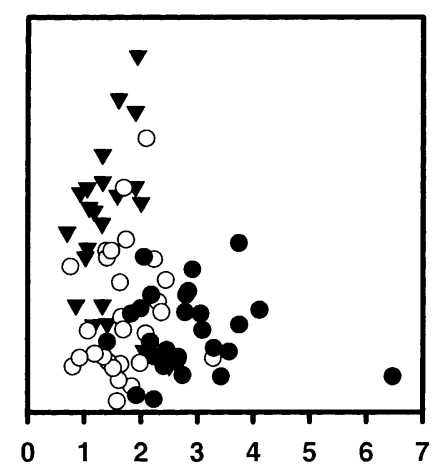

(B)

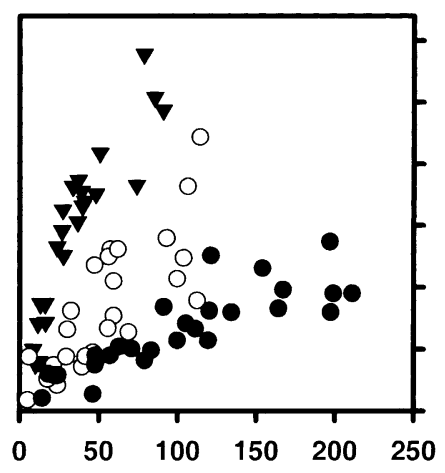

(C) $N_{\text {canopy }}\left(\mathrm{kg} \mathrm{N} \mathrm{ha}^{-1}\right)$

Fig. 2. (A) Plot of LUE $(\varepsilon)$ vs. the canopy average for leaf $\mathrm{N}$ concentration $\left(N_{\text {mass }}\right)$. The regression across all data is $\varepsilon=0.051 N_{\text {mass }}+0.03$ $\left(r^{2}=0.57, P<0.0001, n=105\right)$. (B) Plot of $\varepsilon$ and the canopy average for leaf nitrogen content $\left(N_{\text {area }}, \mathrm{g} \mathrm{N} \mathrm{m}^{-2}\right)$. The two variables are not significantly related across all data $(P=0.07)$. (C) Plot of $\varepsilon$ vs. canopy $\mathrm{N}$ content $\left(N_{\text {canopy }}, \mathrm{kg} \mathrm{Nha}^{-1}\right)$. The two variables are not significantly related across all data $(P=0.36)$. Functional group symbols (all panels): deciduous woody plants, open circles; evergreen woody plants, filled circles; herbaceous species, filled triangles. 

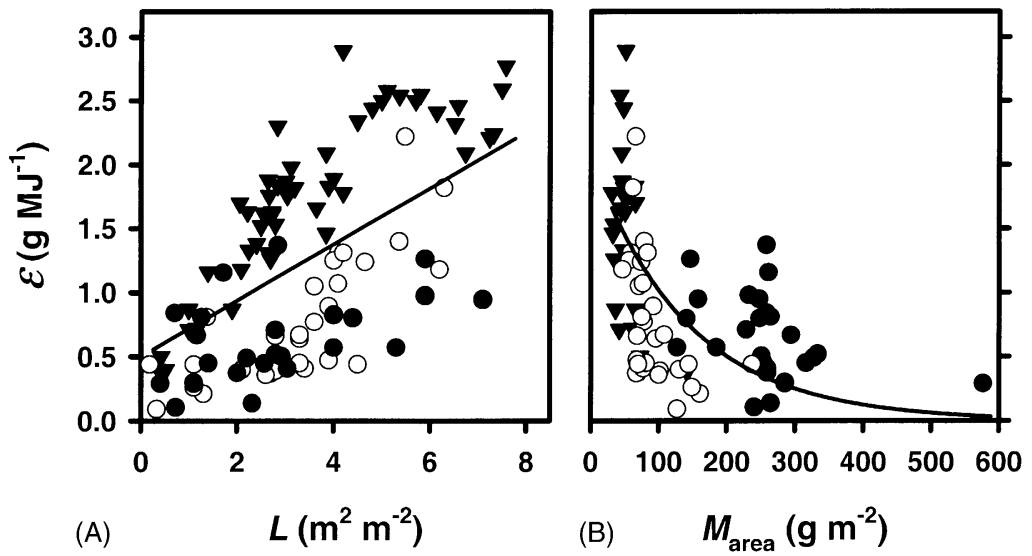

Fig. 3. (A) Relationship between LUE $(\varepsilon)$ and leaf area index $\left(L, \mathrm{~m}^{2} \mathrm{~m}^{-2}\right)$. The regression across all data is $\varepsilon=0.22 L+0.47\left(r^{2}=0.34\right.$, $P<0.0001, n=105)$. (B) Relationship between $\varepsilon$ and the canopy average for leaf mass per unit area $\left(M_{\text {area }}, \mathrm{g} \mathrm{m}^{-2}\right)$. The regression across all data is $\varepsilon=50.8 M_{\text {area }}^{-1}+0.34\left(r^{2}=0.41, P<0.0001, n=78\right)$. Functional group symbols (both panels): deciduous woody plants, open circles; evergreen woody plants, filled circles; herbaceous species, filled triangles.

transport compounds in a leaf or canopy (Field and Mooney, 1986; Evans, 1989; Hollinger, 1996; Reich et al., 1997, 1999; Peterson et al., 1999). While positive correlations between $\varepsilon$ and measures of foliar $\mathrm{N}$ have been observed by several investigators (Sinclair and Horie, 1989; Muchow and Sinclair, 1994; Gimenez et al., 1994; Bange et al., 1997a; Choudhury, 2001), such relationships are typically narrow in scope (within species or among similar species). When data are pooled among ecologically disparate plants (e.g., Fig. 2) a compelling overall trend rarely emerges. But, when we account for variation in $M_{\text {area }}$, we see convergence in the relation between $\varepsilon$ and $N_{\text {canopy }}$ across species, functional groups and environments (Fig. 1).

We believe that the role of $M_{\text {area }}$ in the $\varepsilon$ index ( $\left.\left[N_{\text {canopy }} / f_{\mathrm{PAR}}\right] / M_{\text {area }}\right)$ reflects its negative influence on the efficiency of $\mathrm{N}$ use in leaf photosynthesis (PNUE, $\mu \mathrm{mol} \mathrm{Cg}^{-1} \mathrm{~N} \mathrm{~s}^{-1}$ ). Although a clear link between $M_{\text {area }}$ and leaf-level PNUE has been established (Field and Mooney, 1986; Reich et al., 1997, 1998; Poorter and Evans, 1998; Green and Kruger, 2001), a similar role for $M_{\text {area }}$ at the canopy level has seldom been explored. Atkin et al. (1998) found evidence for the latter, as canopy $\mathrm{N}$ productivity (quotient of net biomass gain and canopy $\mathrm{N}$ content) was negatively related to the canopy average for $M_{\text {area }}$ across several species of Acacia. The mechanistic link between PNUE (or N productivity) and $M_{\text {area }}$ has not been fully resolved, but the available evidence points to limitations on photosynthesis imposed by severe intra-leaf light gradients (Osborne and Raven, 1986; Terashima and Hikosaka, 1995; Reich et al., 1997, 1998; Green and Kruger, 2001) and/or resistance to $\mathrm{CO}_{2}$ diffusion (Lloyd et al., 1992; Parkhurst, 1994; Poorter and Evans, 1998; Garnier et al., 1999) within high- $M_{\text {area }}$ leaves.

The observed curvilinearity in the relation between $\varepsilon$ and the index (Fig. 1) is not surprising given the expectation that the sensitivity of $\varepsilon$ to changes in the index should decrease beyond a certain threshold. In other words, at some point there is diminished benefit of further increases in $N_{\text {canopy }}$ (relative to $f_{\text {PAR }}$ ) or decreases in $M_{\text {area }}$ owing to biophysical limitations. This might help to explain why $\mathrm{N}$ fertilization or other cultural treatments that further increase an already high index do not always yield noticeable gains in $\varepsilon$ (e.g., Flénet and Kiniry, 1995).

\subsection{Unexplained variation in $\varepsilon$}

The difference between herbaceous and woody data in the intercept of the $\varepsilon$ vs. index relationship (Fig. 1) may arise in part from differences in $\mathrm{C}$ allocation. While there is little evidence to support a general difference between the two groups in $\mathrm{C}$ allocation belowground (Hunt and Cornelissen, 1997; Gower 
et al., 1999), Dewar (1996) calculated that respiratory costs of maintaining a large woody stem would result in a decrease in $\varepsilon$. Other factors, such as variation in stomatal conductance, $\mathrm{N}$ allocation to photosynthetic vs. non-photosynthetic chemistry within the foliage, canopy structure and/or tissue construction costs, may also be involved (Evans, 1989; Goetz and Prince, 1998; Green et al., 2001). Ares and Fownes (2001) found that the $\varepsilon$ of forest stands was negatively correlated with ${ }^{13} \mathrm{C}$ discrimination $\left(\delta^{13} \mathrm{C}\right)$, indicating that canopy light utilization may have been enhanced by increased stomatal conductance.

Additional $\varepsilon$ variation can arise from a litany of potential sources, including unmeasured differences in canopy light reflection, temporal variability in canopy chemical or morphological attributes, soil moisture depletion, high atmospheric vapor pressure deficits, extreme air temperatures and other short-term stresses that compromise photosynthetic performance (Osborne and Raven, 1986; Stockle and Kiniry, 1990; Goyne et al., 1993; Runyon et al., 1994; Dewar, 1996; Poorter and Evans, 1998), as well as undetected effects of herbivory or disease (Madeira et al., 1994). Climate-mediated differences in the ratio of diffuse to direct-beam radiation and maintenance respiration can also affect $\varepsilon$ (Dewar, 1996; Bange et al., 1997b; Goetz and Prince, 1998; Choudhury, 2001). We anticipate that data on these factors and their influences could readily be incorporated as modifiers of the fundamental relationship between $\varepsilon$ and the index.

\subsection{Conclusions and potential applications of the $\varepsilon$ index}

Among all of the potential determinants that we examined, the proposed index appeared to provide the best overall integration of the numerous biophysical and biochemical factors that culminated in a wide range of LUEs. While its predictive capability is ecologically informative, the index's most significant contribution may lie in its incorporation into APAR models, which could substantially improve remotely sensed estimates of terrestrial NPP. Modelers already have access to accurate estimates of APAR for terrestrial ecosystems (Goetz and Prince, 1998), and there are or may soon be feasible technologies, such as hyperspectral imaging systems, for accurately quantifying canopy L (Goetz and Prince, 1998; Levy and
Jarvis, 1999; Turner et al., 1999) and, either directly or indirectly, $N_{\text {mass }}$ (Martin and Aber, 2001; Johnson, 2001; Inoue and Penuelas, 2001). Thus, while estimates of one or both of the principal components of the index ( $N_{\text {canopy }}$ and $\left.M_{\text {area }}\right)$ may remain difficult to obtain, remotely sensed values for components of its mathematical equivalent ( $N_{\text {mass }}$ and $\left.L\right)$ are potentially within reach.

Although a wide variety of data have been included in our analysis, the breadth of the index's applicability remains uncertain. Additional research should further examine the index's utility across other species, functional groups, ecosystems and photosynthetic pathways (especially $\mathrm{C}_{4}$ ). Of particular note, canopy attributes ( $N_{\text {canopy }}, N_{\text {mass }}, L$ and $M_{\text {area }}$ ) embodied in the index are known to be sensitive to changes in climate and atmospheric chemistry (Ceulemans and Mousseau, 1994; Haxeltine and Prentice, 1996; Pritchard et al., 1999; Saxe et al., 2001). Thus, the index (if shown to be widely applicable) could not only facilitate the development of improved $\varepsilon$ estimates for modeling terrestrial NPP and but also enhance our ability to predict vegetation responses to global change.

\section{References}

Ares, A., Fownes, J.H., 2001. Productivity, resource use, and competitive interactions of Fraxinus uhdei in Hawaii uplands. Can. J. For. Res. 31, 132-142.

Atkin, O.K., Schortemeyer, M., McFarlane, N., Evans, J.R., 1998. Variation in the components of relative growth rate in ten Acacia species from contrasting environment. Plant Cell Environ. 21, 1007-1017.

Bange, M.P., Hammer, G.L., Rickert, K.G., 1997a. Effect of specific leaf nitrogen on radiation use efficiency and growth of sunflower. Crop Sci. 37, 1201-1207.

Bange, M.P., Hammer, G.L., Rickert, K.G., 1997b. Effect of radiation environment on radiation use efficiency and growth of sunflower. Crop Sci. 37, 1208-1214.

Belanger, G., Richards, J.E., 1997. Growth analysis of timothy grown with varying N nutrition. Can. J. Plant Sci. 77, 373-380.

Campbell, G.S., Norman, J.M., 1998. Introduction to Environmental Biophysics, 2nd ed. Springer, New York, 286 pp.

Campbell, C.S., Heilman, J.L., McInnes, K.J., Wilson, L.T., Medley, J.C., Wu, G., Cobos, D.R., 2001. Seasonal variation in radiation use efficiency of irrigated rice. Agric. For. Meteorol. $110,45-54$.

Ceulemans, R., Mousseau, M., 1994. Effects of elevated atmospheric $\mathrm{CO}_{2}$ on woody plants. New Phytol. 127, 425-446. 
Choudhury, B.J., 2001. Modeling radiation and carbon-use efficiencies of maize, sorghum, and rice. Agric. For. Meteorol. 106, 317-330

Dewar, R.C., 1996. The correlation between plant growth and intercepted radiation: an interpretation in terms of optimal plant nitrogen content. Ann. Bot. 78, 125-136.

Duru, M., Ducrocq, H., Tirilly, V., 1995. Modeling growth of cocksfoot (Dactylis glomerata L.) and tall fescue (Festuca arundinacea Schreb.) at the end of spring in relation to herbage nitrogen status. J. Plant Nutr. 18, 2033-2047.

Evans, J.R., 1989. Photosynthesis and nitrogen relationships in leaves of $\mathrm{C}_{3}$ plants. Oecologia 78, 9-19.

Field, C.B., Mooney, H.A., 1986. The photosynthesis-nitrogen relationship in wild plants. In: Givnish, T.J. (Ed.), On the Economy of Plant Form and Function. Cambridge University Press, New York, pp. 25-55.

Field, C.B., Randerson, J.T., Malstrom, C.M., 1995. Global net primary production: combining ecology and remote sensing. Remote Sens. Environ. 51, 74-88.

Flénet, F., Kiniry, J.R., 1995. Efficiency of biomass accumulation by sunflower as affected by glucose requirement of biosynthesis and leaf nitrogen content. Field Crops Res. 44, 119-127.

Garnier, E., Salager, J.-L., Laurent, G., Sonié, L., 1999. Environmental limits on net primary production and light-use efficiency across the Oregon transect. Ecol. Appl. 4, 226-237.

Geeske, J., Gamon, J.A., Field, C.B., 1997. Production efficiency of sunflower: the role of water and nitrogen stress. Remote Sens. Environ. 62, 176-188.

Gholz, H.L., Fisher, R.F., 1982. Organic-matter production and distribution in slash pine (Pinus elliottii) plantations. Ecology 63, 1827-1839.

Gholz, H.L., Fisher, R.F., Pritchett, W.L., 1985. Nutrient dynamics in slash pine plantation ecosystems. Ecology 66, 647-659.

Gholz, H.L., Vogel, S.A., Cropper, W.P., McKelvey, K., Ewel, K.C., Teskey, R.O., Curran, P.J., 1991. Dynamics of canopy structure and light interception in Pinus elliottii stands, North Florida. Ecol. Monogr. 61, 33-51.

Gimenez, C., Connor, D.J., Rueda, F., 1994. Canopy development, photosynthesis and radiation-use efficiency in sunflower in response to nitrogen. Field Crops Res. 38, 15-27.

Giunta, F., Motzo, R., Deidda, M., 1995. Effects of drought on leaf area development and nitrogen uptake of durham wheat grown in a Mediterranean environment. Aust. J. Agric. Res. 46, 99-111.

Goetz, S.J., Prince, S.D., 1998. Variability in carbon exchange and light utilization among boreal forest stands: implications for remote sensing of net primary production. Can. J. For. Res. $28,375-389$.

Gower, S.T., Kucharik, C.J., Norman, J.M., 1999. Direct and indirect estimation of leaf area index, $f_{\mathrm{APAR}}$ and net primary production of terrestrial ecosystems. Remote Sens. Environ. 70, $29-51$.

Goyne, P.J., Milroy, S.P., Lilley, J.M., Hare, J.M., 1993. Radiation interception, radiation use efficiency and growth of barley cultivars. Aust. J. Agric. Res. 44, 1351-1366.

Green, D.S., 1998. Interrelation of leaf structure and function among deciduous broad-leaved and evergreen needle-leaved trees in southern Wisconsin. Ph.D. Dissertation. University of Wisconsin, Madison, 95 pp.

Green, D.S., Kruger, E.L., 2001. Light-mediated constraints on leaf function correlate with leaf structure among deciduous and evergreen tree species. Tree Physiol. 21, 1341-1346.

Green, D.S., Kruger, E.L., Stanosz, G.R., Isebrands, J.G., 2001. Light-use efficiency of native and hybrid poplar genotypes at high levels of intracanopy competition. Can. J. For. Res. 31, 1030-1037.

Haxeltine, A., Prentice, I.C., 1996. A general model for the lightuse efficiency of primary production. Funct. Ecol. 10, 551-561.

Hollinger, D.Y., 1996. Optimality and nitrogen allocation in a tree canopy. Tree Physiol. 16, 627-634.

Hui, D., Luo, Y., Cheng, W., Coleman, J.S., Johnson, D.W., Sims, D.A., 2001. Canopy radiation and water-use efficiencies as affected by elevated $\left[\mathrm{CO}_{2}\right]$. Global Change Biol. 7, 75-91.

Hunt, R., Cornelissen, J.H.C., 1997. Components of relative growth rate and their interrelations in 59 temperate species. New Phytol. 135, 395-417.

Inoue, Y., Penuelas, J., 2001. An AOTF-based hyperspectral imaging system for field use in ecophysiological and agricultural applications. Int. J. Remote Sens. 22, 3883-3888.

Jarvis, P.G., Leverenz, J.W., 1983. Productivity of temperate, deciduous and evergreen forests. In: Lange, O.L., Nobel, P.S., Osmond, C.B., Ziegler, H. (Eds.), Encyclopedia of Plant Physiology, New Series, Plant Physiological Ecology IV, vol. 12D. Springer, Heidelberg, pp. 233-280.

Johnson, L.F., 2001. Nitrogen influence on fresh-leaf NIR spectra. Remote Sens. Environ. 78, 314-320.

Jose, S., Gillespie, A.R., 1996. Aboveground production efficiency and canopy nutrient contents of mixed-hardwood forest communities along a moisture gradient in the central United States. Can. J. For. Res. 26, 2214-2223.

Kiniry, J.R., McCauley, G., Xie, Y., Arnold, J.G., 2001. Rice parameters describing crop performance of four US. Cultivars Agron. J. 93, 1354-1361.

Landsberg, J.J., Prince, S.D., Jarvis, P.G., McMurtrie, R.E., Luxmoore, R., Medlyn, B.E., 1997. Energy conversion and use in forests: an analysis of forest production in terms of radiation utilisation efficiency $(\varepsilon)$. In: Gholz, H.L., Nakane, K., Shimoda, H. (Eds.), The Use of Remote Sensing in the Modeling of Forest Productivity. Kluwer Academic Publishers, Boston, pp. 273-298.

Levy, P.E., Jarvis, P.G., 1999. Direct and indirect measurements of LAI in millet and fallow vegetation in HAPEX, Sahel. Agric. For. Meteorol. 97, 199-212.

Lloyd, J., Syvertsen, J.P., Kriedemann, P.E., Farquhar, G.D., 1992. Low conductances for $\mathrm{CO}_{2}$ diffusion from stomata to the sites of carboxylation in leaves of woody species. Plant Cell Environ. $15,873-899$.

Madeira, A.C., Clark, J.A., Rossal, S., 1994. Growth and light interception in field bean (Vicia faba) infected by Ascochyta fabae. J. Agric. Sci. 123, 225-232.

Martin, M.E., Aber, J.D., 2001. High spectral resolution remote sensing of forest canopy lignin, nitrogen, and ecosystem processes. Ecol. Appl. 7, 431-443. 
McMurtrie, R.E., Gholz, H.L., Linder, S., Gower, S.T., 1994. Climate factors controlling the productivity of pine stands: a model-based analysis. Ecol. Bull. 43, 173-188.

Medlyn, B.E., 1998. Physiological basis of the light use efficiency model. Tree Physiol. 18, 167-176.

Monteith, J.L., 1972. Solar radiation and productivity in tropical ecosystems. J. Appl. Ecol. 9, 747-766.

Monteith, J.L., 1977. Climate and efficiency of crop production in Britain. Phil. Trans. Roy. Soc. B 281, 277-294.

Muchow, R.C., 1990. Effect of leaf nitrogen and water regime on the photosynthetic capacity of Kenaf (Hibiscus cannabinus L.) under field conditions. Aust. J. Agric. Res. 41, 845-852.

Muchow, R.C., Sinclair, T.C., 1994. Nitrogen response of leaf photosynthesis and canopy radiation use efficiency in field-grown maize and sorghum. Crop Sci. 34, 721-727.

Osborne, B.A., Raven, J.A., 1986. Light absorption by plants and its implications for photosynthesis. Biol. Rev. 61, 1-61.

Parkhurst, D.F., 1994. Diffusion of $\mathrm{CO}_{2}$ and other gases inside leaves. New Phytol. 126, 449-479.

Peterson, A.G., Field, C.B., Ball, J.T., Amthor, J.S., Drake, B., et al., 1999. Reconciling the apparent difference between massand area-based expressions of the photosynthesis-nitrogen relationship. Oecologia 118, 144-150.

Pierce, L.L., Running, S.W., Walker, J., 1994. Regional-scale relationships of leaf area index to specific leaf area and leaf nitrogen content. Ecol. Appl. 4, 313-321.

Poorter, H., Evans, J.R., 1998. Photosynthetic nitrogen-use efficiency of species that differ inherently in specific leaf area. Oecologia 116, 26-37.

Pritchard, S.G., Rogers, H.H., Prior, S.A., Peterson, C.M., 1999. Elevated $\mathrm{CO}_{2}$ and plant structure: a review. Global Change Biol. 5, 807-837.

Raison, R.J., Myers, B.J., 1992. The biology of forest growth experiment: linking water and nitrogen availability to the growth of Pinus radiata. For. Ecol. Manage. 52, 279-308.

Raison, R.J., Myers, B.J., Benson, M.L., 1992. Dynamics of Pinus radiata foliage in relation to water and nitrogen stress. I. Needle production and properties. For. Ecol. Manage. 52, 139-158.

Reich, P.B., Walters, M.B., Ellsworth, D.S., 1997. From tropics to tundra: global convergence in plant functioning. Proc. Natl. Acad. Sci. USA 94, 13730-13734.

Reich, P.B., Ellsworth, D.S., Walters, M.B., 1998. Leaf structure (specific leaf area) modulates photosynthesis-nitrogen relations: evidence from within and across species and functional groups. Funct. Ecol. 12, 948-958.

Reich, P.B., Ellsworth, D.S., Walters, M.B., Vose, J.M., Gersham, C., Volin, J.C., Bowman, W.D., 1999. Generality of leaf trait relationships: a test across biomes. Ecology 80, 1955-1969.

Renewable Resources Data Center, 2002. National Renewable Energy Laboratory. Solar Radiation Resource Information, US Department of Energy. http://rredc.nrel.gov/solar (accessed on September 17, 2002).
Ruimy, A., Dedieu, G., Saugier, B., 1994. Methodology for the estimation of terrestrial net primary production from remotely sensed data. J. Geophys. Res. 99, 5263-5284.

Runyon, J., Waring, R.H., Goward, S.N., Welles, J.M., 1994. Environmental limits on net primary production and lightuse efficiency across the Oregon transect. Ecol. Appl. 4, 226-237.

Russell, G., Jarvis, P.G., Monteith, J.L., 1989. Absorption of radiation by canopies and stand growth. In: Russell, G., Marshall, B., Jarvis, P.G. (Eds.), Plant Canopies: Their Growth, Form and Function. Cambridge University Press, Cambridge, pp. 21-39.

Sadras, V.O., Wilson, L.J., 1997. Growth analysis of cotton crops infested with spider mites. 1. Light interception and radiation-use efficiency. Crop Sci. 37, 481-491.

SAS, 2000. SAS Statistical Package for PC, Version 8.1. SAS Institute Inc., Cary, NC.

Saxe, H., Cannell, M.G.R., Johnsen, B., Ryan, M.G., Vourlitis, G., 2001. Tree and forest functioning in response to global warming. New Phytol. 149, 369-399.

Shaver, G.R., Chapin, F.S., 1991. Production:biomass relationships and element cycling in contrasting arctic vegetation types. Ecol. Monogr. 61, 1-31.

Sinclair, T.R., Horie, T., 1989. Leaf nitrogen, photosynthesis, and crop radiation use efficiency: a review. Crop Sci. 29, 90-98.

Sinclair, T.R., Muchow, R.C., 1999. Radiation use efficiency. Adv. Agron. 66, 215-265.

Snowdon, P., Benson, M.L., 1992. Effects of combinations of irrigation and fertilization on the growth and aboveground biomass production of Pinus radiata. For. Ecol. Manage. 52, 87-116.

Stockle, C.O., Kiniry, J.R., 1990. Variability in crop radiation-use efficiency associated with vapor-pressure deficit. Field Crops Res. 25, 171-181.

Terashima, I., Hikosaka, K., 1995. Comparative ecophysiology of leaf and canopy photosynthesis. Plant Cell Environ. 18, 1111-1128.

Teskey, R.O., Gholz, H.L., Cropper, W.P., 1994. Influence of climate and fertilization on net photosynthesis of mature slash pine. Tree Physiol. 14, 1215-1227.

Turner, D.P., Cohen, W.B., Kennedy, R.E., Fassnacht, K.S., Briggs, J.M., 1999. Relationships between leaf area index and Landsat Tm spectral vegetation indices across three temperate zone sites. Remote Sens. Environ. 70, 52-68.

Weiss, A., Norman, J.M., 1985. Partitioning solar radiation into direct and diffuse, visible and near-infrared components. Agric. For. Meteorol. 34, 205-213.

Wright, G.C., Hammer, G.L., 1994. Distribution of nitrogen and radiation use efficiency in peanut canopies. Aust. J. Agric. Res. 45, 565-574. 